\title{
EDUCATION AS A CAUSE FOR PARTICIPATION IN POLITICS: A CASE STUDY IN BULGARIA
}

\author{
Petrana STOYKOVA \\ Chief Assistant Professor, Faculty of Philosophy, Department of Sociology, \\ South-West University "Neofit Rilski", Republic of Bulgaria \\ E-mail: petrana_stoikova@swu.bg
}

\begin{abstract}
Political participation is a very important factor for liberal democracy. All forms of political participation in government contribute to democracy. In addition, the effects of participation are considered to be substantive in a very different way, for instance by providing an individual with direct usefulness and by contributing to personal contentment and satisfaction with life in general. A priori, from a subject subordinate to the state in all preliberal regimes, the individual in contemporary democracies becomes an unavoidable factor in political processes. Given that, the analysis in this article is based on the characteristics of the Bulgarian democratic model. The main purpose of the study is the current challenges to civic engagement and the importance of education for the political participation of Bulgarian citizens to be analyzed. The applied methodology is a combination of a theoretical approach to political participation and analysis of the data gathered from various quantitative surveys (European Social Survey, other representative and non-representative sociological surveys). The results of these surveys reveal the important role of education for the participation of Bulgarians in politics. The influence of education on the alleged interest in politics, the trust in institutions, the participation in political elections and on other forms of civic engagement has been studied. The need for political socialization and the motivation of young Bulgarians to participate more actively in the political sphere is emphasized.
\end{abstract}

Keywords: Education, Political Participation, Political Socialization, Bulgaria 


\section{Introduction}

\subsection{Typologies of Political Participation}

There are various forms of participation of citizens and social groups in the political process. These forms are different in the existing political systems and political regimes. Such differences are manifested in the entire institutional and non-institutional infrastructure, determining the opportunities for the presence and influence of the individual on politics (Karasimeonov, 1997). According to Georgi Fotev, in all political regimes "whether monarchical or republican, aristocratic, oligarchic, tyrannical, totalitarian or democratic, all nationals and respectively all citizens participate in political life, but, of course, in different ways" (Fotev, 2001).

Political participation in the authoritarian and especially in the totalitarian regimes is strictly regulated. It is to the greatest extent enforced by the rulers in order to consolidate power. Totalitarian regimes are characterized by the purposeful organization of the political participation of citizens as a kind of ritual for legitimizing the respective regime. This regulated type of participation excludes the execution of all those fundamental rights and freedoms of citizens, especially in the political sphere, affecting the authority of the government (Karasimeonov, 1997).

Until the era of the great revolutions that gave rise to liberal democracy, many citizens are excluded from direct participation in the political process. Liberal democracy is a qualitative development of citizens' political participation. It is related to the affirmation of the idea of individual freedom as a fundamental element of the democratic political process. The other basic principles raised by the theorists of liberal democracy and later enshrined in the constitutional texts such as people's sovereignty, the rule of law, separation of powers, equality of citizens, political pluralism, etc., represent a significant political transition to a new type of citizen participation in the political process (Karasimeonov, 1997).

The democratic regimes, especially the most developed ones, create many opportunities for citizens to participate in the political process. Political participation is an extremely important factor for liberal democracy, as its effectiveness depends to a large extent on the activity of civil society, on the citizens' involvement in the political process, on their ability to regularly and freely express their attitude to the activities of the government, the parties and individual politicians. According to the authors of "The Civic Culture" Gabriel Almond and Sidney Verba, it is no coincidence that theorists of democracy from Aristotle to Bryce have emphasized that "the democracies are supported by active civic participation in civil affairs, a high level of awareness of public affairs and a widespread sense of civic responsibility" (Almond \&Verba, 1998). One of the common definitions of political participation is given by the French political scientist Pascal Perino, who sees this participation as "a certain homogeneous set of activities through which the mass of citizens come into contact with the specific world of power" (Karasimeonov, 1997). These 
activities in a democracy can include both "conventional" forms (voting or supporting an election campaign) and "unconventional" forms (such as occupying a factory) (José María Maraval, 1992). The difference between the two groups (most often the forms of political participation are grouped into two different groups - conventional and unconventional participation) is significant - the individual does not risk conflict with the law in conventional participation, but he/she runs a conscious high risk of legal repression in unconventional participation (Todorov, 2012). Anthony Todorov notes that most authors understand political participation as the legitimate activities of private citizens that aim to more or less directly influence the selection of management staff or their actions (Todorov, 2012). Regarding the direct and indirect influence of citizens, it is important to keep in mind Verba, Schlozman and Brady's understanding that political participation is an activity "which has the purpose or effect of influencing government actions - either directly, by influencing the design or implementation of public policy, or indirectly by influencing the choices of the people who make those policies" (Verba, Schlozman \& Brady, 1995).

In general, three main types of political participation in representative democracies can be identified: passive, which is mainly expressed by participation in elections; active participation in the political process, which is manifested by participation in the activities of political parties during election campaigns and in various forms of extra-parliamentary activities; and apathy or distance from the political process, or political non-participation as a result of voluntary choice (Karasimeonov, 1997). Passive political participation can also be defined as representative (electoral), active - as including nonrepresentative and direct participation (Panov, 2016), and apathy or distance can be considered as tacit political participation (in terms of understanding that political inaction has the character of political action).

Voting is the most important form of political participation in a democracy. Nathan Sharansky and Don Dermer note that although there are a number of features that are commonly associated with modern democratic society - rule of law, constitution, independent court, political parties, stable opposition, freedom of religion, freedom of the press, etc., most people associate democracies mostly with holding elections. They emphasize that "certainly no one will consider a country democratic, if its government is not elected" (Sharansky \& Dermer, 2009).

To the second type of political participation - in addition to the participation in political parties' activities, the active participation in the political process can include the functioning of the so-called "civil society", which is a "network of various non-governmental institutions, which are strong enough to be opposed to the state" (Gellner, 1996).

This type of participation also includes public protests, participation in strikes and demonstrations, public consultations (better known as town hall meetings), duty of jurors, filing a lawsuit, signing a petition, writing a letter to a civil servant, political actors or newspapers, blogging about a political issue, donating money to a cause, volunteering for a campaign, economic support for 
parties and groups, joining an activist or interest group, organizing a group, holding public office, occupying a building in an act of protest, committing a terrorist act and others (Bergström, 2006; White, 2016). The rapid development of digital information and communication technologies makes it possible to include new forms of political activity. As long as they are aimed at expressing political motives online, activities such as posting comments, opinions, information or audiovisual materials on websites, blogs or SNS can be included in the concept of political participation (Hosch-Dayican, 2014). Prerequisites for the impact of these activities are the provision of free access to serious political analysis, articles, documents, press releases, photos and videos, a mobile application as an additional source of information, the ability to record open political debates by live broadcast, translation during important international meetings and others (Marin \& Georgieva, 2017). The global citizens become increasingly dependent on communication skills, trust and dialogue (Kiryakova-Dineva, T., Hadzhipetrova-Lachova, M.\& Chankova, Y., 2017).

According to M. Hafner-Fink, S1. Kurdija and S. Uhan "together with social changes, such as the development of late modernity, individualisation and the emergence of new communication technologies such as the internet, new forms of citizens' political activites are emerging in the form of political consumerism and various on-line forms of participation" (Hafner-Fink, Kurdija, Sl. \& Uhan, 2017). The authors share the opinion that the old forms of participation are being revised (for example, many conventional forms of participation (e.g. communication with politicians) are moving to the internet, while some unconventional forms of participation are in fact becoming convetional). The conventional - inconventioanl dichotomy needs to be replaced by a differentiation between institutionalised and individualised forms of political participation (Hafner-Fink, Kurdija, Sl. \& Uhan, 2017).

The roles the media play in activating political citizenship and participation must be emphasized (the theories of democratic political participation have long since recognized these roles) (Fenton, 2014). New media are changing political culture by creating a broader and more heterogeneous basis for political participation (Hadjiev, 2015). Media coverage plays a significant role in creating awareness and engagement. News matters at a fundamental level to society. It is an important factor for the strengthening of democracy. The creation of anti-political mood and the thwart of political participation in the public sphere largely depend on news (Fenton, 2014).

Apathy (distance) from the political process or political non-participation as a result of voluntary choice is the opposite form of the other two types of political participation (a distinction is made between "apathy" and "abstinence", as the second concept means a conscious decision not to vote or to participate in the political process). Non-participation in politics can be the result of the influence of various factors - lack of interest in politics; insufficient political knowledge (low political and legal culture); distrust in politicians and the political system; the belief that one's own vote does not matter (it will be wasted, deliberately unaccounted for or melted by the purchased vote); the atrophy of political skills; 
discrimination, feelings of under-representation or complete underrepresentation; lack of a political alternative; fear of political engagement; voter fatigue from frequent political elections and others. The lack of political activity or the low level of political activity refers mainly to non-participation in elections, which leads to problems in the functioning of the democratic system, calling into question its legitimacy and existence.

According to Ronald Inglehard, raising the level of education, the growing integration of women in public life, and finally the development of priority values for the new generations imply passive support for elites (classic elections). At the same time, they reinforce unconventional forms of participation that can exert an active influence on them (Brod, 2012). Philip Brod adds that even if citizens become more skeptical or reticent, they will be more determined to act when they perceive that they have a real opportunity for influence (Brod, 2012). Perceiving this opportunity and its rational assessment is directly related to the developed political skills, formed mainly through education. It is the main reason for all three types of political participation (passive, active or apathy (distance) from politics).

According to Martin Belov, the prerequisites for adequate participation of citizens in the political process can be divided into two major groups - legal and non-legal (background). In the first place, it is important to regulate the relevant institutions empowering citizens to participate in the political process. Equally important are the non-legal (background) prerequisites for adequate and rational civic participation in this process. One of the background conditions is related to the level of legal and political culture of citizens, as well as to the level of their general education (Belov, 2010). The author adds, referring to history, that "education is not a guarantee of maturity, fairness and effectiveness of decisions made by citizens either as part of the electorate or as holders of public authorities. At the same time, however, having at least a minimum level of education, as well as legal and political culture and experience is important for the formation of a rational choice between personal or substantive alternatives, especially when it comes to making complex and long-term strategic decisions" (Belov, 2010). Apart from the fact that the educated citizen is more informed and careful in his / her choice than the uneducated one, he/she is also characterized by higher civic activity. According to Persson, education is a prerequisite for increasing interest in politics, for greater involvement in the electoral process and for reaching the norm of being a good citizen (Persson, 2013).

\subsection{Civic Engagement versus Political Engagement}

While political engagement is a more narrow term that refers to direct participation in formal city governance and administration, civic engagement is a broad term that implies being an active citizen in any way in service to the community (Civic Engagement versus Political Engagement, 2012).

According to Thomas Ehrlich, author of "Civic Responsibility and Higher Education", "Civic engagement means working to make a difference in the 
civic life of our communities and developing the combination of knowledge, skills, values and motivation to make that difference. It means promoting the quality of life in a community, through both political and non-political processes.

A morally and civically responsible individual recognizes himself or herself as a member of a larger social fabric and therefore considers social problems to be at least partly his or her own; such an individual is willing to see the moral and civic dimensions of issues, to make and justify informed moral and civic judgments, and to take action when appropriate" (Civic engagement).

As there are many types of civic engagement, some examples can be mentioned (Civic Engagement versus Political Engagement, 2012):

- participating in community and volunteer organizations

- participating in elections by volunteering or voting

- writing letters to political representatives

- campaigning in various issues through social media

- membership in associations and groups

- rallying and protesting

- signing petitions

- engagement with local government politics

- $\quad$ sitting on city councils, regional boards, Advisory Committees, Task Forces, boards

- making presentations to the council

Civic engagement is multidimensional and includes knowledge, skills, and identity, all of which can be encouraged with appropriate educational experiences (Van Camp \& Baugh, 2016). Education is an important factor for both civic engagement and political engagement. Various investigations have shown that there is a correlation between the level of education and political competence. According to Henk Dekker "the higher the level of education which has been achieved, the more individuals feel compelled to participate in politics, the more interested they are in political affairs, and the more they do in fact take part in political activities, such as working for political campaigns" (Dekker, 1991). The author concludes that "level of education does, therefore, in itself have an influence on political involvement” (Dekker, 1991). A person's education is a very strong predictor of who participates in politics.

Civic knowledge is fundamental to democratic citizenship. It is essential that people become well-informed citizen and build their own opinions and viewpoints, so to be aware of government structures and functions, and to be able to participate effectively in civic and political life. To this end, one must not only be literate as much as possible (as most of the Icelanders like to read and are among the most literate nations in the world) (Chankova, 2021), but one has also purposefully to improve one's own civic (including electoral) culture. 


\subsection{Theoretical models of the relationship between education and political participation}

In the literature, three models dominate the discussion on the links between education and political participation - "the absolute education model", "the preadult socialization model", and "the relative education model" (Figure 1). Taken together, they clarify the understanding of the relationship between education and political participation (Persson, 2013).

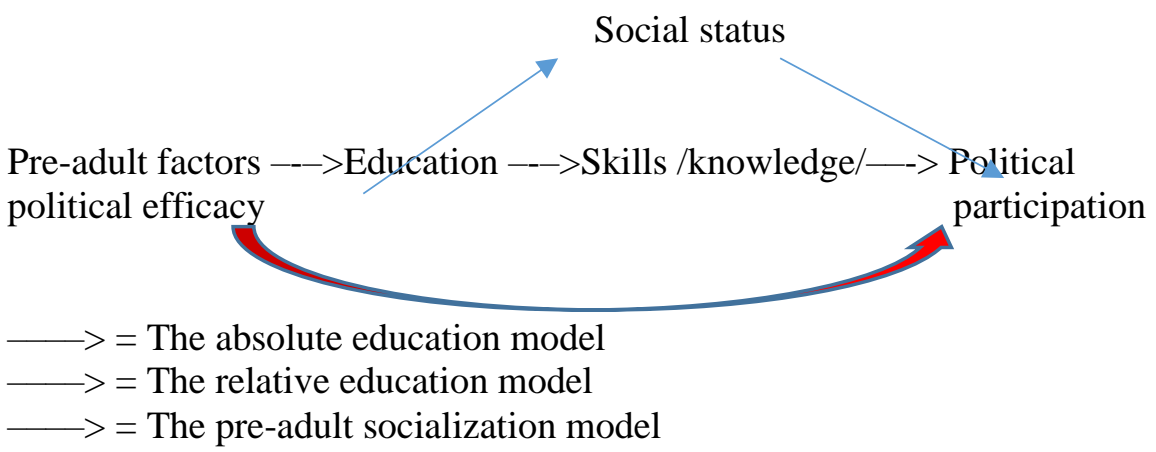

Figure 1. Theoretical models of the relationship between education and political participation (Persson, 2013)

The absolute education model is sometimes synonymously referred to as the "education as a cause view". According to this model, education has a causal effect on political participation. The first model is referred to as the absolute education model since the effects of education are not dependent on the level of education in the environment. This absolute education model regards education effects as an individual level cognitive process (Persson, 2013). Persson claims that "education increases civic skills and political knowledge which function as the causal mechanisms triggering participation. This is also sometimes referred to as the "cognitive pathway", i.e., what individuals learn at school has positive effects on their cognitive ability, which in turn affects participation". Most important for political participation is the increased verbal and cognitive proficiency that comes with higher education. This is because language is crucial to understanding and communicating about politics. Persons with high verbal and cognitive proficiency can more easily understand political messages and in turn articulate their own political views. Moreover, education is supposed to increase political knowledge and provide a better understanding of the political system. According to this model, people who understand how the political system works will also understand the importance of participating in the system. In addition to skills and knowledge, it has also been argued that education triggers political efficacy (Persson, 2013). According to Jackson, "schooling enhances both the belief that the potential voter can influence what the government does (external efficacy) and the belief that the potential voter 
has the competence to understand and participate in politics (internal efficacy)". Hence, education supposedly increases citizens' beliefs that they can effectively play a role in the political process" (Persson, 2013).

The extreme alternative to the absolute education model is the pre-adult socialization model. The second model "suggests that the relationship (in question) could be explained with reference to self-selection effects; preadult factors affect both educational choice as well as political participation in adulthood" (Persson, 2013). According to some researchers, education works as a proxy for factors such as family socioeconomic status, the political socialization in home environments and personal characteristics such as cognitive abilities ("education as a proxy view"). Other authors argue that factors such as intelligence (Luskin, 1990), genetic factors (Alford, Funk and Hibbing, 2005) or personality types affect political participation in adulthood (Mondak and Halperin, 2008), and these factors could also affect educational choice. Persson remarks that: "It is factors like these, rather than education that affect participation according to the pre-adult socialization model" (Persson, 2013).

The third model is synonymously referred to as "the sorting model" and actually offers a revisionist view. The relative education model takes a different causal path as compared to the other two models. According to the sorting model, there is an indirect effect of education on political participation via social status (Nie, Junn and Stehlik-Barry, 1996). Many studies have shown that at any given time people with higher education participate to a larger extent in political activities, but this is not tantamount to claiming that the increasing level of education of the population as a whole, leads to an aggregate increase in political participation. In the literature, high social status is defined as having a central social network position in society. Persson points out that "the relative education model has been presented as a potential solution to one of the major puzzles in political behavior research: the paradoxical relationship between education and participation at the micro- and macrolevels" (Persson, 2013). The impact of education on political participation is hypothesized to be relative rather than absolute (Persson, 2013).

The three models described above reveal the complexity of the study of the factors determining the intensity and forms of political participation. However, the role of political knowledge and skills for civic activity is indisputable. Education is a major factor in the formation of a quality political elite, relatively rational electoral choice and higher levels of participation in various civic initiatives. The impact of education on political participation is not easy to measure and involves the application of different research methods and approaches. 


\section{Data and Methods}

The analysis of civic engagement and the relationship between education and political participation of Bulgarian citizens is based on data from quantitative studies. Some of them allow the application of statistical methods (Chi-square analysis) for testing hypotheses, which allow to draw the necessary conclusions.

Data from the following quantitative surveys are discussed: 1) Empirical sociological research conducted by scientific and private organizations in the period from 1989 to 1993 . They give a more general idea of the interest in politics and the role of education on the political participation of Bulgarian citizens in the first years of the period of transition to democracy; 2) European Social Survey (ESS) - Round 5 (2010), Round 6 (2012) and Round 9 (2018). These waves of research include Bulgaria. By individual indicators, the results from 2018 for Bulgaria are compared with the summarized data for the 29 countries that are part of the ESS9. The survey is one of the largest fundamental scientific survey of social attitudes, beliefs and behaviours of individuals in European countries. Based on it, the importance of education as a reason for political participation is evaluated. The free access to the whole database made it possible to apply Chi-square analysis; 3) National survey of the Rego Institute (Rego Institute, 2020) conducted among 2,000 adult Bulgarian citizens in the period from 21 October 2020 to 27 October 2020. The selection of respondents is by quota, based on the following demographic characteristics - type of settlement, gender and age. Despite the fact that the education is not a criterion for the selection of interviewees, the sample relatively accurately reflects the educational structure of the adult Bulgarian population. As a sociologist at this Institute, my full access to the data allowed me to explore in more depth the influence of education on individuals' interest in politics (through the application of Chi-square analysis); 4) National representative survey conducted in December 2020 by Exacta Research Group. The analysis of the data represents the profile of the Bulgarian citizens who are permanently not interested in politics, as well as of the interviewees, whose interest in politics is growing. The education criterion lies in the basis of these two profiles; 5) National representative surveys of Gallup International for the period from 1989 to 2019, related to the trust of Bulgarian citizens in the institutions; 6) Exit poll of the sociological agency "Trend", held during the elections for the European Parliament in 2019. The educational structure of the voters is used in the analysis; and 7) Unrepresentative quantitative study on "Rural life and the challenges for the young people", implemented within the project "We, the young people, can". This project is implemented by the Ministry of Youth and Sports and the NGO "Because we can". The goal of study are the young people aged 15 to 29 whose permanent residence is one of the villages in the municipalities of Petrich and Sandanski. The sample size is 98 people, and the period of conducting the research is from 1 December 2019 to 22 December 2019. As a sociologist under this project, I processed the data with the SPSS program. 


\section{Results and Discussion}

\subsection{Interest in politics}

Data from a variety of empirical sociological research (ESR) conducted in the period from the beginning of the transition to democracy (1989) to 2001 show a relatively high interest of Bulgarian citizens in politics (Blagoeva-Taneva, 2002). A representative survey of the Institute of Sociology at the Bulgarian Academy of Sciences (BAS) from 1991 contains the question "Are you interested in politics?". More than $85 \%$ of the respondents give a positive answer to this question. According to data from a survey conducted in 1993, political interest remains relatively high. Respondents are asked "How important is politics in your life?". The results are, as follows: a total of $72 \%$ of them indicated the answers "very important" and "somewhat important" (Political Barometer, MBMD, January, 1993). This high interest of citizens in politics is combined with a high assessment of good orientation in it. Half of the respondents share the opinion that politics is "not so complicated" (ESR of the Institute of Sociology at BAS, December, 1991; ESR of National Center for Public Opinion Research, January, 1991; ESR of MBMD, September, 1992 and October, 1993), and only a few of them share the opposite view that politics is "a complicated thing and ordinary people do not understand it" (BlagoevaTaneva, 2002). In this period, education did not have a significant impact on the interest in politics and the political participation of Bulgarian citizens.

However, following Bulgaria's accession to the European Union, there has been a gradual and significant reduction in the share of citizens interested in politics. Data from the ESS5 (2010) show a significant decline in the interest of Bulgarian citizens in politics (the sample size is 2434 people). Of the respondents who answered the question "How interested are you in politics?" less than $50 \%(47,9 \%)$ indicate the options "very interested" (9,4\%) and "quite interested" (38,5\%). The results of the ESS6 (2012) show a slight increase of the interest in politics - a total of $51,1 \%$ answered with "very interested" $(11,1 \%)$ and "quite interested" (40\%), but the data from ESS - Ninth Wave (2018) reveal a drastic decline - a total of $30 \%$ are those who indicated the answers "very interested" (5,2\%) and "quite interested" (24,8\%). In general, from the beginning of the period of transition to 2018, the interest of Bulgarian citizens in politics has decreased about three times (ESS). The application of the Chi-square analysis on the data from the ESS9 (2018) for Bulgaria shows that education influences the interest in politics (Pearson Chi-Square Asymptotic Significance (2-sided) is, $0000^{\circ}$ ). There is a greater interest in politics among higher educated Bulgarian citizens (Table 1). Although Cramer's coefficient $(0,194)$ shows that the strength of the relationship between interest in politics and the level of education is weak, the mentioned relationship still exists.

The results of a National Survey conducted by Rego Institute (Rego Institute, 2020) among 2000 adult Bulgarian citizens in the period from 21 October 2020 to 27 October 2020 (the selection of respondents is by quota, based on the 
Education as a cause for participation in politics...

following demographic characteristics: type of settlement, sex and age) also confirm that there is a relationship between education and interest in politics (Pearson Chi-Square - Asymptotic Significance (2-sided) is „,000“). The respondents with higher education are more interested in politics than those with lower education (Table 2). Cramer's coefficient is 0,161 , which means that the strength of the relationship between the two variables is weak.

Table 1

Interest in Politics by Highest Level of Education 2018 (ESS9, Bulgaria)

\begin{tabular}{|c|c|c|c|c|c|}
\hline & \multicolumn{3}{|c|}{ Highest level of Education } & \multirow[b]{2}{*}{ Total } \\
\hline & & $\begin{array}{l}\text { Primary and } \\
\text { lower than } \\
\text { Primary } \\
\text { Education }\end{array}$ & $\begin{array}{l}\text { Secondary } \\
\text { Education }\end{array}$ & $\begin{array}{l}\text { Higher } \\
\text { Education }\end{array}$ & \\
\hline \multirow{4}{*}{$\begin{array}{l}\text { How } \\
\text { interested } \\
\text { in Politic } \\
\text { are you? }\end{array}$} & $\begin{array}{l}\text { Very } \\
\text { interested }\end{array}$ & $3,0 \%$ & $5,5 \%$ & $7,7 \%$ & $5,2 \%$ \\
\hline & $\begin{array}{l}\text { Quite } \\
\text { interested }\end{array}$ & $14,5 \%$ & $26,9 \%$ & $34,7 \%$ & $24,8 \%$ \\
\hline & $\begin{array}{l}\text { Hardly } \\
\text { interested }\end{array}$ & $32,6 \%$ & $40,2 \%$ & $39,8 \%$ & $37,8 \%$ \\
\hline & $\begin{array}{l}\text { Not at all } \\
\text { interested }\end{array}$ & $49,8 \%$ & $27,5 \%$ & $17,8 \%$ & $32,2 \%$ \\
\hline \multicolumn{2}{|l|}{ Total } & $100,0 \%$ & $100,0 \%$ & $100,0 \%$ & $100,0 \%$ \\
\hline
\end{tabular}

Table 2

Interest in Politics by Highest level of Education 2020 (Rego Institute)

\begin{tabular}{|c|c|c|c|c|c|}
\hline & \multicolumn{3}{|c|}{ Highest level of Education } & \multirow[b]{2}{*}{ Total } \\
\hline & & \begin{tabular}{|lr} 
Primary and \\
lower than \\
Primary \\
Education \\
\end{tabular} & $\begin{array}{l}\text { Secondary } \\
\text { Education }\end{array}$ & $\begin{array}{l}\text { Higher } \\
\text { Education }\end{array}$ & \\
\hline \multirow{4}{*}{$\begin{array}{l}\text { How } \\
\text { interested } \\
\text { in Politic } \\
\text { are you? }\end{array}$} & $\begin{array}{l}\text { Very } \\
\text { interested }\end{array}$ & $8,6 \%$ & $10,1 \%$ & $20,2 \%$ & $13,9 \%$ \\
\hline & $\begin{array}{l}\text { Quite } \\
\text { interested }\end{array}$ & $29,0 \%$ & $40,0 \%$ & $43,4 \%$ & $40,3 \%$ \\
\hline & $\begin{array}{l}\text { Hardly } \\
\text { interested }\end{array}$ & $27,8 \%$ & $32,8 \%$ & $24,7 \%$ & $29,1 \%$ \\
\hline & $\begin{array}{l}\text { Not at al } \\
\text { interested }\end{array}$ & $34,6 \%$ & $17,1 \%$ & $11,7 \%$ & $16,6 \%$ \\
\hline \multicolumn{2}{|l|}{ Total } & $100,0 \%$ & $100,0 \%$ & $100,0 \%$ & $100,0 \%$ \\
\hline
\end{tabular}

*The author is a sociologist at the Rego Institute (https://rego.bg/, 2020) 
The data from a more recent nationally representative survey, conducted in December 2020 by Exacta Research Group, lend support to the outlined trend of the declining interest of Bulgarian citizens in politics. 74,5\% of Bulgarians are not interested in politics in the country, and 25,5\% are interested in it. 17,6\% of the interviewees identify themselves as permanently uninterested in politics. In the greatest percent of cases, these are young and low-educated people, Roma people and villagers. There is a very small share of respondents who indicate that their interest in politics has been growing recently - only $7,7 \%$. These are mostly educated people and right-wing voters (Nearly $75 \%$ of Bulgarians are not interested in Politics in our country, 2020).

In addition to interest in politics, trust in political institutions is also an important prerequisite for political participation. The lack of interest in political life and distrust in state institutions presupposes the manifestation of the third type of political participation - apathy or distance.

\subsection{Trust in the political institutions and the legal system}

Similarly to their declining interest in politics, the majority of Bulgarian citizens do not trust political institutions. According to a Gallup International analysis from 1989 to 2019 (30 years after the beginning of democratic changes), "along the whole period, during the 1990s and later on, the Parliament and government have low levels of trust" (The Main Political Institutions 2019). Furthermore, the authors of the analysis emphasize that "even during economically successful and calm mandates, the attitude of Bulgarians towards institutions remains negative" (The Main Political Institutions 2019).

Data from the ESS9 (2018) also confirm that Bulgarian citizens have a relatively low level of trust in various institutions (the sample size is 2198 people). The average confidence assessment (measured on a scale from 0 to 10: 0 - No trust at all; 10 - Complete trust) of political parties, politicians, police, legal system and the Bulgarian Parliament are, as follows: 2,14; 2,12; 3,80; 2,99 and 2,49. At the same time, these assessments are lower than the overall average assessments for the 29 countries surveyed, respectively: 3,$61 ; 3,66 ; 6,42 ; 5,33$ and 4,52 (Figure 2). 
Education as a cause for participation in politics...

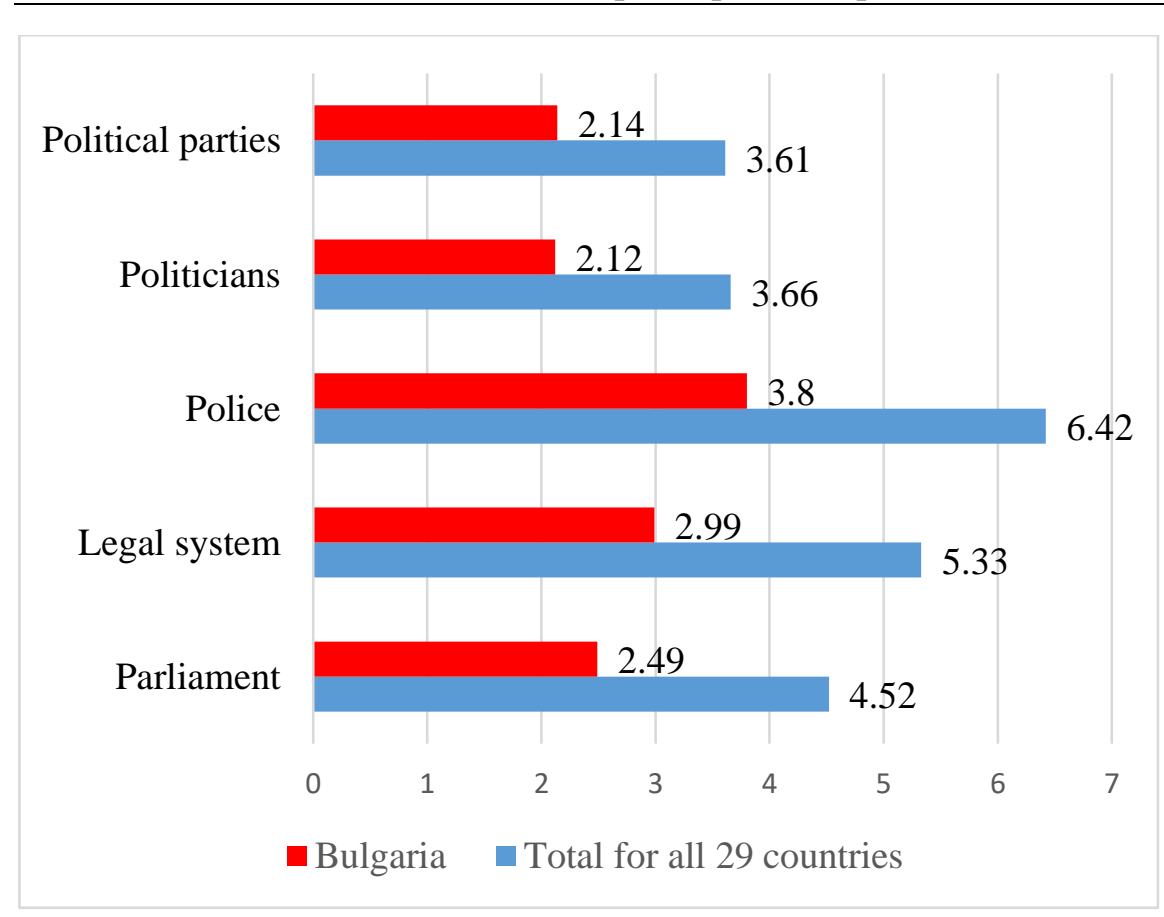

\section{Figure 2. Average assessments of trust in institutions 2018 (ESS9)}

The application of the Chi-square analysis reveals that there is a very weak relationship between the level of education and the trust in the Parliament, legal system and police (the alternative hypothesis is accepted, but the value of Cramer's coefficient is very low - below 0,1 ). Higher educated citizens (with completed secondary and higher education) trust less in these institutions compared to lower educated ones (with completed primary and lower than primary education). The respondents from the first group more often give an assessment above the average (between 6 and 10) compared to the lower educated representatives of the second group. The trust of Bulgarian citizens in the other two surveyed subjects - politicians and political parties is not determined by their education (the null hypothesis is true).

\subsection{Voting in political elections}

Education is a factor that influences the interest in politics and the trust of Bulgarian citizens in some of the state institutions. The manifestation of the various types of political participation depends on the interest in politics and the trust in the government.

A special place in the political development of Bulgaria is occupied by the Tarnovo Constitution, adopted on 16 April 1879. According to Voyn Bozhinov, the assumptions that this is "the most democratic constitution" and "a gospel of freedom" are largely true (Bozhinov, 2017). If we interpret literally the text referring to the electorate, there is no division into "women" and "men", that 
is, equal suffrage is given to both sexes. According to Todor Galunov, "as of the date of the adoption of the Tarnovo Constitution, women do not have the right to vote in world election practice", which shows that "Tarnovo legislators, albeit unintentionally, create democratic texts that are ahead of their time" (Galunov, 2014). The adoption of this constitution creates good conditions for the beginning of civic participation in the political processes.

According to Antony Todorov, the question "Why do citizens participate in the elections?" is the subject of limited interest in historical research in Bulgaria (Todorov, 2001). He notes that most post-Liberation elections are a caricature of democracy and an unreliable source of information, and that the same mechanisms of electoral motivation operate as in the other European countries. The author claims that "the more educated people, those interested in politics, those connected for some reason to political parties, those involved in larger business are the first voters in liberated Bulgaria" (Todorov, 2001). In his analysis, Todorov also argues that the adoption of elections as a democratic procedure requires some knowledge and interest in public activity above all (Todorov, 2001).

Summing it up, the relationship between the participation in political elections and the knowledge in politics refers to both the emerging Bulgarian state after the adoption of the Tarnovo Constitution in 1879 and the transition to democracy after 1898. In his analysis of the Bulgarian political culture of 2011, Antony Todorov contends that "civic activist culture in contemporary Bulgarian society remains relatively marginal, shared in the more educated circles" (Todorov, 2011). It could be assumed that education has some influence on the process of voting in political elections.

The profile of the Bulgarian voter, outlined eight years later (2019) on the basis of exit polls and the results of a national survey of electoral attitudes at the end of 2020, shows very clearly the importance of education for electoral participation. The data from the exit poll conducted by the sociological agency "Trend" during the European Parliament elections in 2019 are, as follows: of the Bulgarian citizens who voted in these elections, $44 \%$ have higher education, $45,1 \%$ have completed secondary education, and $10,9 \%$ have primary and lower than primary education (Voter Profile (Exit Polls from the 2019 European elections, 2019). According to the results of a national survey of the Rego Institute, conducted among 2000 adult Bulgarian citizens in the period from 21 October 2020 to 27 October 2020 (quoted above), the share of respondents with higher education who will not vote, if the parliamentary elections were tomorrow is $11,8 \% ; 15,7 \%$ of the secondary school graduates will not go to the electoral station; and $20,4 \%$ of the respondents with primary and lower than primary education will not exercise their right to vote (Rego Institute, 2020). The educational structure of the working age population (25 64 years) by 2019 reveals that the share of persons with higher education is $28,1 \%$, with secondary education $-54,3 \%$, and with primary and lower than primary education $-17,5 \%$, hence it can be concluded that citizens with higher level of education exercise their active suffrage more often (Baev, 2021). 


\subsection{Civic engagement}

Some types of civic engagement are explored in the ESS9 (2018). The data reveal the relatively low civic activity of Bulgarian citizens. Concerning each of the following indicators: Contacted a politician or government official last 12 months; Worked in a political party or action group last 12 months; Worked in another organisation or association last 12 months; Signed a petition last 12 months; Taken part in a lawful public demonstration last 12 months; Boycotted certain products last 12 months: and Posted or shared anything about politics online last 12 months, the share of Bulgarian respondents who answered "yes" is significantly smaller than the corresponding total share of all respondents from the 29 countries included in the survey (Figure 3).

According to the results of the Chi-square analysis, education has an impact on the participation of Bulgarian citizens in the various forms of civic activity studied. Although the Cramer's coefficient with respect to the indicators listed above is respectively: 0,$143 ; 0,105 ; 0,104 ; 0,113 ; 0,091 ; 0,105$ and 0,114 (i.e. the dependence between education and the different indicators is weak), education is an important prerequisite for the formation of higher civic engagement. No doubt, the highest civic participation is observed among the higher educated population (Tables 3-9)

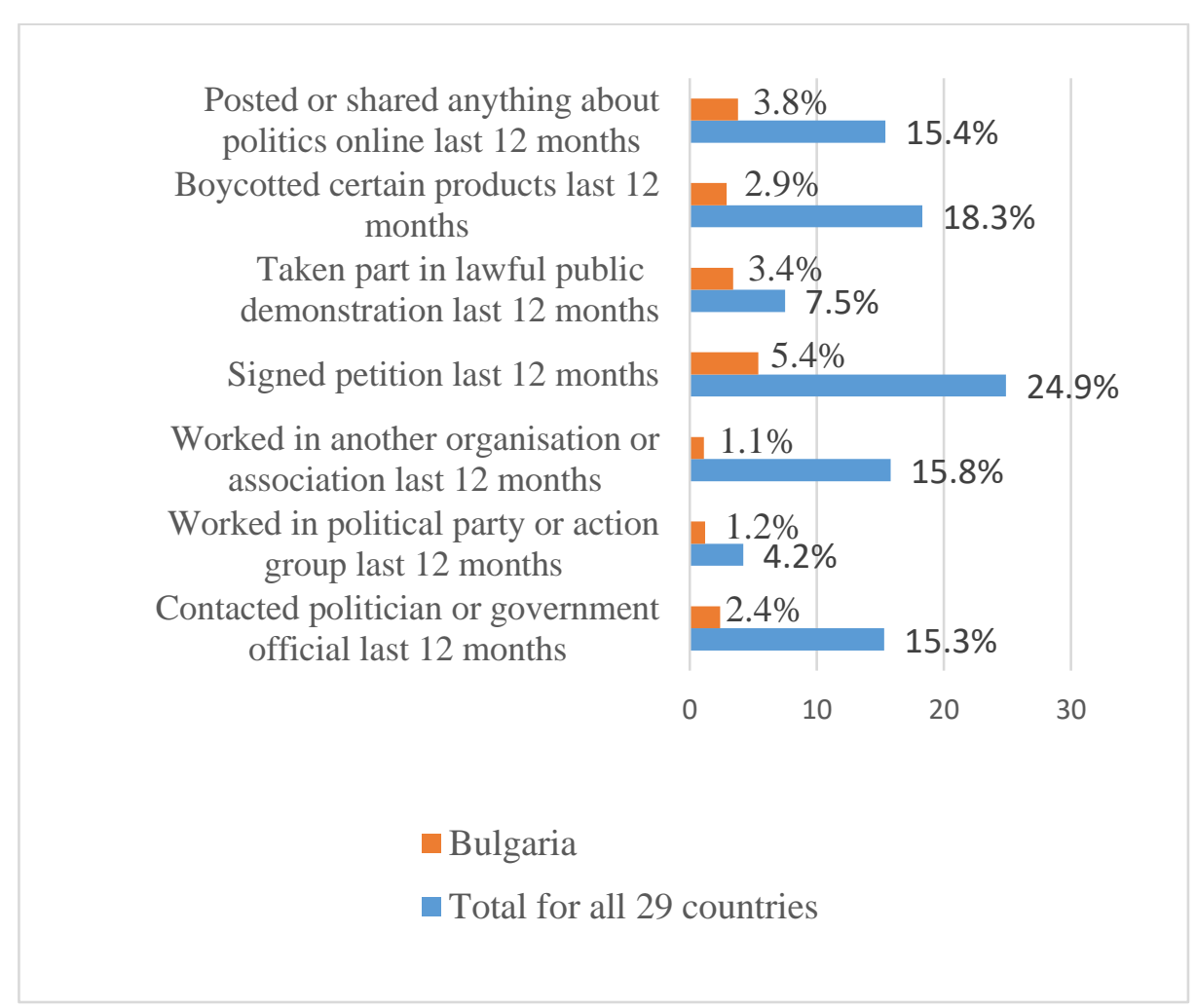

Figure 3. Types of civic engagement 2018 (ESS9) 
Table 3

Contacted a politician or government official last 12 months by gender (ESS9 - 2018)

\begin{tabular}{|c|c|c|c|c|}
\hline & Education & & & \\
\hline & $\begin{array}{ll}\text { Primary } & \text { and } \\
\text { lower } & \text { than } \\
\text { Primary } & \\
\text { Education } & \\
\end{array}$ & $\begin{array}{l}\text { Secondary } \\
\text { Education }\end{array}$ & $\begin{array}{l}\text { Higher } \\
\text { Education }\end{array}$ & Total \\
\hline Contacted aYes & $0,5 \%$ & $1,8 \%$ & $6,5 \%$ & $2,4 \%$ \\
\hline \begin{tabular}{|lll} 
government & No \\
official last & 12 \\
months & & \\
\end{tabular} & $99,5 \%$ & $98,2 \%$ & $93,5 \%$ & $97,6 \%$ \\
\hline Total & $100,0 \%$ & $100,0 \%$ & $100,0 \%$ & $100,0 \%$ \\
\hline
\end{tabular}

\section{Table 4}

Worked in a political party or action group last 12 months by gender (ESS9 - 2018)

\begin{tabular}{|c|c|c|c|c|}
\hline & \multicolumn{3}{|l|}{ Education } & \multirow[b]{2}{*}{ Total } \\
\hline & $\begin{array}{lr}\text { Primary and } \\
\text { lower than } \\
\text { Primary } \\
\text { Education }\end{array}$ & $\begin{array}{l}\text { Secondary } \\
\text { Education }\end{array}$ & $\begin{array}{l}\text { Higher } \\
\text { Education }\end{array}$ & \\
\hline Worked in a Yes & $0,2 \%$ & $0,9 \%$ & $3,4 \%$ & $1,2 \%$ \\
\hline $\begin{array}{l}\text { political party or } \\
\text { action group last } \\
12 \text { months }\end{array} \mid$ & $99,8 \%$ & $99,1 \%$ & $96,6 \%$ & $98,8 \%$ \\
\hline Total & $100,0 \%$ & $100,0 \%$ & $100,0 \%$ & $100,0 \%$ \\
\hline
\end{tabular}


Education as a cause for participation in politics...

Table 5

Worked in another organisation or association last 12 months by gender (ESS9 - 2018)

\begin{tabular}{|l|l|l|l|l|}
\hline & \multicolumn{2}{|l|}{ Education } & \\
\cline { 2 - 5 } & $\begin{array}{l}\text { Primary and } \\
\text { lower than } \\
\text { Primary } \\
\text { Education }\end{array}$ & $\begin{array}{l}\text { Secondary } \\
\text { Education }\end{array}$ & $\begin{array}{l}\text { Higher } \\
\text { Education }\end{array}$ & Total \\
\hline $\begin{array}{l}\text { Worked in another Yes } \\
\text { organisation or No } \\
\begin{array}{l}\text { association last 12 } \\
\text { months }\end{array}\end{array}$ & $0,8 \%$ & $0,4 \%$ & $3,1 \%$ & $1,1 \%$ \\
\hline Total & $99,2 \%$ & $99,6 \%$ & $96,9 \%$ & $98,9 \%$ \\
\hline
\end{tabular}

Table 6

Signed a petition last 12 months by gender (ESS9 - 2018)

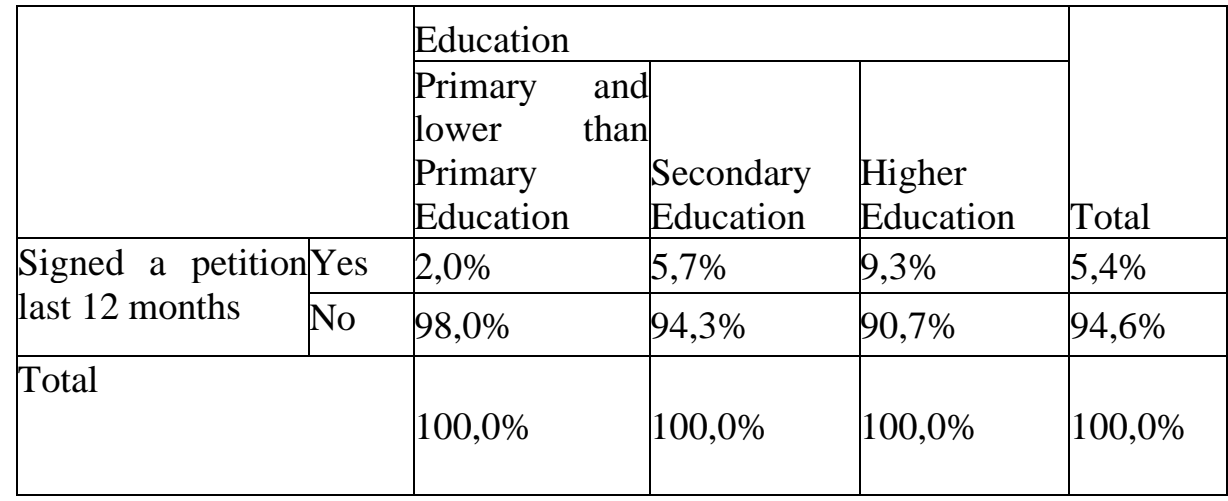

Table 7

Taken part in a lawful public demonstration last 12 months by gender (ESS9 - 2018)

\begin{tabular}{|c|c|c|c|c|}
\hline & \multicolumn{3}{|l|}{ Education } & \multirow[b]{2}{*}{ Total } \\
\hline & $\begin{array}{ll}\text { Primary and } \\
\text { lower } \\
\text { Primary } & \\
\text { Education } & \\
\end{array}$ & $\begin{array}{l}\text { Secondary } \\
\text { Education }\end{array}$ & $\begin{array}{l}\text { Higher } \\
\text { Education }\end{array}$ & \\
\hline Taken part in a Yes & $0,8 \%$ & $4,2 \%$ & $4,9 \%$ & $3,4 \%$ \\
\hline $\begin{array}{l}\text { lawrul public } \\
\text { demonstration last } \\
12 \text { months }\end{array}$ & $99,2 \%$ & $95,8 \%$ & $95,1 \%$ & $96,6 \%$ \\
\hline Total & $100,0 \%$ & $100,0 \%$ & $100,0 \%$ & $100,0 \%$ \\
\hline
\end{tabular}


Table 8

Boycotted certain products last 12 months by gender (ESS9 - 2018)

\begin{tabular}{|l|l|l|l|l|}
\hline \multicolumn{2}{|l|}{} & \multicolumn{2}{|l|}{ Education } & \\
\cline { 2 - 5 } & $\begin{array}{l}\text { Primary and } \\
\text { lower than } \\
\text { Primary } \\
\text { Education }\end{array}$ & $\begin{array}{l}\text { Secondary } \\
\text { Education }\end{array}$ & $\begin{array}{l}\text { Higher } \\
\text { Education }\end{array}$ & Total \\
\hline $\begin{array}{l}\text { Boycotted certain } \\
\text { products last 12 } \\
\text { months }\end{array}$ & $1,0 \%$ & $2,7 \%$ & $6,0 \%$ & $2,9 \%$ \\
\hline Notal & $99,0 \%$ & $97,3 \%$ & $94,0 \%$ & $97,1 \%$ \\
\hline
\end{tabular}

Table 9

Posted or shared anything about politics online last 12 months by gender (ESS9 - 2018)

\begin{tabular}{|l|l|l|l|l|}
\hline & \multicolumn{2}{|l|}{ Education } & \\
\cline { 2 - 4 } & $\begin{array}{l}\text { Primary and } \\
\text { lower than } \\
\text { Primary } \\
\text { Education }\end{array}$ & $\begin{array}{l}\text { Secondary } \\
\text { Education }\end{array}$ & $\begin{array}{l}\text { Higher } \\
\text { Education }\end{array}$ & Total \\
\hline $\begin{array}{l}\text { Posted or shared Yes } \\
\text { anything about No } \\
\text { politics online last } \\
12 \text { months }\end{array}$ & $1,1 \%$ & $3,8 \%$ & $7,4 \%$ & $3,8 \%$ \\
\hline Total & $98,9 \%$ & $96,2 \%$ & $92,6 \%$ & $96,2 \%$ \\
\hline
\end{tabular}

Given the fact that the younger part of the population has a better educational structure, it can be assumed that it is mostly young people who take part in the various types of civic engagement. However, among young Bulgarians there are apathetic attitudes towards the political processes. According to Kaloyan Metodiev, in the transition period, the group of young people decreases both in terms of quantity and quality (Metodiev, 2012). The growing illiteracy among young Bulgarians affects not only the economic dynamics, but also the politics. The same author argues that in the second half of the transition, phenomena such as buying and selling of votes during elections, lack of any political culture, marginalization of entire communities and social apathy "are thriving" (Metodiev, 2012). He concludes that a whole new generation is growing, which will not only become a burden, but also a threat to the political development and stability of the country (Metodiev, 2012).

At present, the civic engagement of Bulgarian youth continues to be a challenge for the Bulgarian state and society. According to Peter-Emil Mitev, the data from a current large-scale survey (held in 2018 or 2019) conducted by Gallup International (commissioned by the Friedrich Ebert Foundation) demonstrates 
that "the young Bulgarians feel politically alienated", and regarding the participation in elections and political careers ,that only 3-4\% of young people show such interest, and they are not the best" (Young Bulgarians: More and More Citizens of the World, without Interest in Politics, 2019).

The results of an unrepresentative quantitative survey on "Rural life and the challenges for young people", conducted in the period from 01 December 2019 to 22 December 2019 among 98 young people, aged 15 to 29 with permanent residence in some of the villages in the municipalities of Petrich and Sandanski, also reveal many disturbing tendencies related to the interest of young people in politics and their political culture.

According to the surveyed young people, the mayor of the municipality, the mayor of the village and the inhabitants of the village bear the greatest responsibility for the quality of life in their village (Figure 4).The frequent indication of the villagers' responsibility by the respondents means that civic activity can also be expected from these young people (Stoykova, 2020).

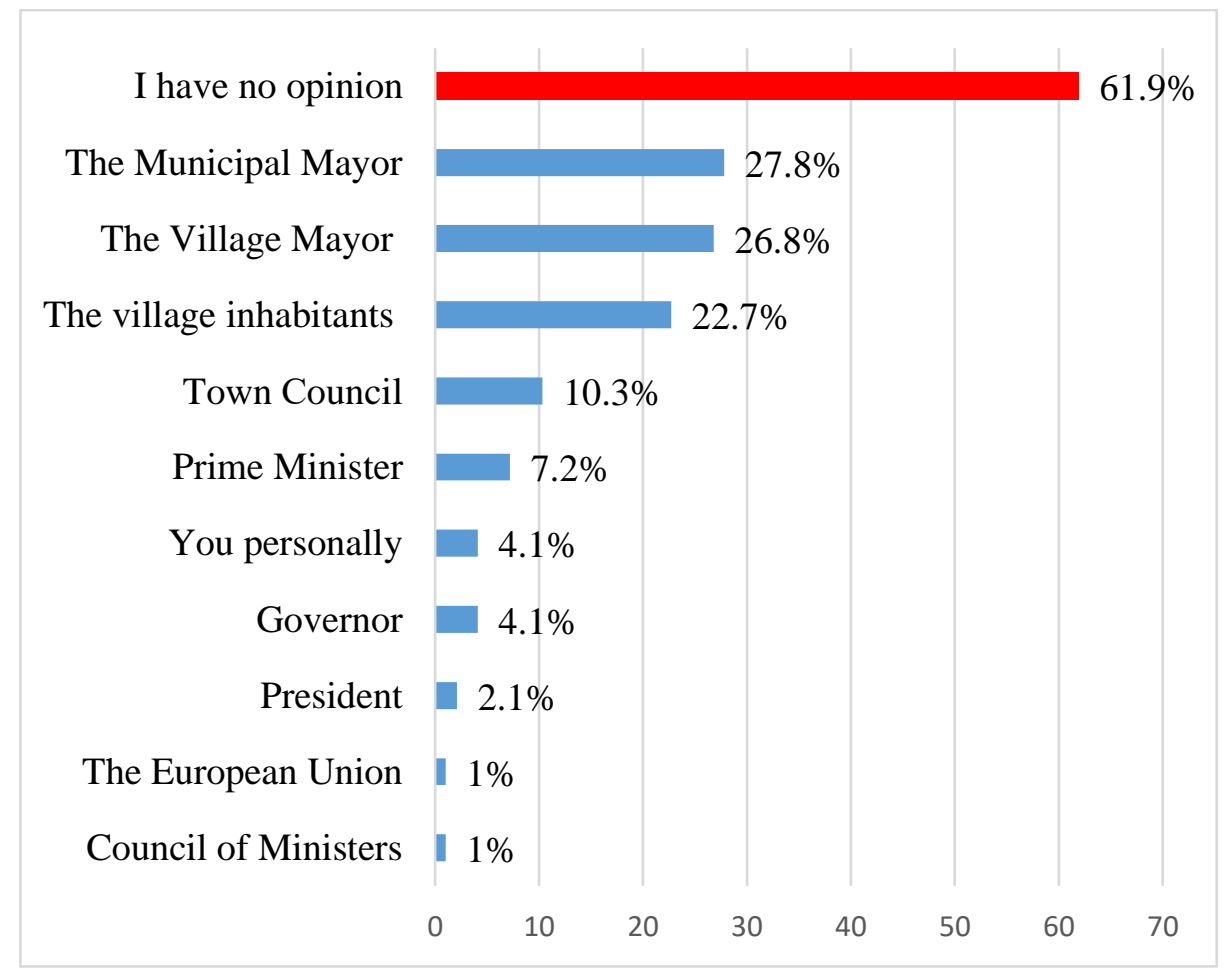

Figure 4. Who is most responsible for the quality of life in your village?

An alarming fact is emerging, when asked "Who is most responsible for the quality of life in your village?", more than half of the respondents $(61,9 \%)$ indicated the option "I have no opinion" (in the municipality of Sandanski this answer was chosen by $88,2 \%$ of the surveyed persons, and in the municipality 
of Petrich by 47,6\%). These data suggest the need to increase the political and legal culture of rural youth, and hence their civic activity (Stoykova, 2020).

\section{Conclusion}

Social science research of political participation encounters the problem of the various types or forms of political participation (Hafner-Fink, Kurdija, S1. \& Uhan, 2017). The expansion in citizen skills and resources enables more people to get engaged in the different forms of participation. Both old and new forms of political participation can be clearly explained through the paradigm of education. Education itself is highly correlated with political knowledge, interest, voter turnout, and other forms of political participation (Neundorf \& Smets, 2017).

Education is an important factor for the increase in the political participation of Bulgarian citizens living in a state of democracy. The declining interest in politics since the beginning of the democratic changes (1989) and the record low trust in the institutions are serious challenges to the normal functioning of the modern political system. The civic engagement of Bulgarians, measured by the ESS, is significantly lower as compared to the other 28 countries included in the survey. The need for political socialization is particularly obvious, and so is the need for specific policies encouraging the promotion of civic engagement.

\section{References $^{1}$}

Almond, G. \& Verba, S. (1998). Гражданската култура [The Civic Culture]. Sofia: Gal-Iko.

Baev, S. (2021). Някои основни характеристики на образованието навъзрастни в България [Major caracteristics of the adult education in Bulgaria]. Sofia: Institute for Research in Education. Retrieved from https://ire-bg.org/wpsite/wp-content/uploads/2021/01/adult-learningin-Bulgaria.pdf

Belov, M. (2010). Гражданското участие в политическия процес. Конституционноправни основи [Civic participation in the Political Process. Constitutional legal bases]. Sofia: Sibi.

Bergström, L. (2006). Political participation_A qualitative study of citizens in Hong Kong. Retrieved from https://www.divaportal.org/smash/get/diva2:5903/FULLTEXT01.pdf

Blagoeva-Taneva, B1. (2002). Българската политическа култура:традици и съвременност [Bulgarian Political Culture. Traditions and modernity]. Sofia: Zahariy Stoyanov.

\footnotetext{
${ }^{1}$ The translation in English language of the references is made by the author.
} 
Bozhinov, V. 2017. Управлението на деветнадесетомайщите (19 май 1934 - 22 януари 1935 година) [The government of those who carried out the coup on May 19 (19 May 1934 - 22 April 1935)]. Sofia: Arka.

Brod, F. (2012). Политическата демокраџия [Political Deтосracy].Sofia: University Publishing House "St. Kliment Ohridski".

Chankova, Y. (2021). Сага за исландския език [The saga of icelandic]. In: Чуждоезиково обучение [Foreign Language Teaching], 48(1), pp. 18-31. doi:10.53656/for21.12saga

Dekker, H. (1991). Political Socialization Theory and Reseach. Retrieved from https://www.researchgate.net/publication/234047064_Political_Social ization_Theory_and_Reseach

Fenton, N. 2014. Defending Whose Democracy? Media Freedom and Media Power. In: Defending Democracy (Nordic and Global Diversities in Media and Journalism), (pp. 31-43). Nordicom, University of Gothenburg.

Fotev, G. (2001). Граници на политиката (сочиологически трактат) [Limits of Politics. A Sociological Treatise]. Sofia: LIK.

Galunov, T. (2014). Мажсоритарната система и парламентарните избори в България: от възстановяването на българската държавност до началото на деветдесетте години на XIX век [The majority system and the parliamentary elections in Bulgaria: from the restoration of the Bulgarian statehood to the beginning of the nineties of the XIX century]. V. Tarnovo: Faber.

Gellner, Er. (1996). Условията на свободата. Гражданското общество и неговите съперници [Conditions of liberty: civil society and its rivals]. Sofia: Obsidian.

Hadjiev, В. (2015). Влиянието на новите медии върху гражданското общество (на примера на развитието на протестните движения $2009-2013$ г. в България) [The influence of new media on Civil Society (On the example of the development of the protests movements in Bulgaria from 2009 to 2013)]. Sofia: University of National and World Economy.

Hafner-Fink, M., Kurdija, Sl. \& Uhan, S. (2017). Social Research: from Paradigmatic Divide to Pragmatic Eclecticism. Wien: Edition Echoraum.

Neundorf, An. \& Smets, K. (2017). Political Socialization and the Making of Citizens. doi: 10.1093/oxfordhb/9780199935307.013.98

Hosch-Dayican, B. (2014). Online political activities as emerging forms of political participation: How do they fit in the conceptual map? (pp. 342-346). Retrieved from https://www.researchgate.net/publication/278259359_Online_politica 1_activities_as_emerging_forms_of_political_participation_How_do_ they_fit_in_the_conceptual_map

José María Maraval. (1992). The meanings of Politics: The subjective foundations of Democracy. In: The Spanish transition to Democracy. 
The Political Process (pp. 199-230). Sofia: Center for the Study of Democracy.

Karasimeonov, G. (1997). Политика и политически институцчии [Politics and Political Institutions]. Sofia: University Publishing House "St. Kliment Ohridski".

Kiryakova-Dineva, T., Hadzhipetrova-Lachova, M., \& Chankova, Y. (2017). Intercultural dialogue for education in the Mediterranean region. EDULEARN17 Proceedings.doi:10.21125/edulearn.2017.1845

Marin, N. \& Georgieva, G. (2017). Някои проблеми, свързани с осигуряването на превод по време на българското председателство на съвета на EC [Some translation issues regarding the Bulgarian Presidency of the Council of the European Union]. In: International Politics, 1/2, pp. 90-96. Retrieved from http://ip.swu.bg/

Metodiev, K. (2012). Поколения и възраст в политиката. Българският npexod [Generations and Age in Politics. The Bulgarian transition]. V. Tarnovo: Faber.

Panov, Tr. (2016). Who Stops Voting and Why? Party Ideology Shift and Voter Demobilisation. European University Institute, Department of Political and Social Sciences. Retrieved from https://cadmus.eui.eu/bitstream/handle/1814/41704/Panov_2016.pdf? sequence $=2 \&$ is Allowed $=\mathrm{y}$

Persson, M. (2013). Does Education Cause Participation in Politics? Kållered: Ineko. Retrieved from https://core.ac.uk/download/pdf/17181452.pdf

Sharansky, N. \& Dermer, R. (2009). В защита на демокращията. Силата на свободата да победиш тиранията и терора [The Case For Democracy: The Power of Freedom to Overcome Tyranny and Terror]. Sofia: Memra.

Stoykova, P. 2020. Гражданската ангажираност на селската младеж: изследване на случая в общините Петрич и Сандански (Република Бълария) [Rural youth civic engagement: a case study in the Municipalities of Petrich and Sandanski (Republic of Bulgaria)]. In: International Journal “Knowledge”, Vol. 38.5, pp. 1165-1171. Print: GRAFOPROM-Bitola.

Todorov, An. (2011). Българската политическа култура и гражданското yчacmue [Bulgarian Political Culture and Civic Participation]. Retrieved from https://library.fes.de/pdf-files/bueros/sofia/08096.pdf

Todorov, An. (2001). Избирателни закони и избирателна активност(примерът на България, 1879-1946) [Electoral Laws and Electoral Dctivity (The example of Bulgaria, 1879-1946)]. Retrieved from https://eedu.nbu.bg/pluginfile.php/139372/mod_resource/content/0/Elactiv.pdf

Todorov, An. (2012). Елементи на политиката. Трактат върху политическото [Elements of Politics (Treatise on the Political)]. Sofia: New Bulgarian University. 
Van Camp, D. \& Baugh, St. (2016). Encouraging Civic Knowledge and Engagement: Exploring Current Events through a Psychological Lens. In: Journal of the Scholarship of Teaching and Learning, Vol. 16, No. 2, April 2016, pp. 14-28. doi: 10.14434/josotl.v16i2.19199

Verba, S., Schlozman, K. L. \& Brady, H. (1995). Voice and equality: Civic voluntarism in American politics. Cambridge: Harvard University Press.

Weitz-Shapiro, R. \& Winters, Matthew S. (2008). Political participation and quality of life. Retrieved from https://www.econstor.eu/bitstream/10419/51523/1/585732140.pdf

\section{Website references}

Civic engagement. The Policy Circle. Retrieved from https://www.thepolicycircle.org/brief/whatswhys-civic-engagement/

Civic Engagement versus Political Engagement. (2012). Retrieved from https://www.ubcm.ca/EN/main/resources/local_government_awarene ss_week/youth-engagement.html

European Social Survey. Retrieved from https://www.europeansocialsurvey.org/

Is citizen participation actually good for democracy? (22.08.2017). Retrieved from https://www.democraticaudit.com/2017/08/22/is-citizenparticipation-actually-good-for-democracy/

Nearly $75 \%$ of Bulgarians are not interested in Politics in our country (17.02.2020). Retrieved from https://news.bg/society/blizo-75-otbalgarite-ne-se-interesuvat-ot-politikata-u-nas.html

Rego Institute. (2020). Retrieved from https://rego.bg/ The main Political institutions 2019 (18.12.2019). Retrieved from https://www.gallupinternational.bg/42694/summary-political-institutions-2019/

Voter profile (Exit polls from the 2019 European elections). Retrieved from https://rctrend.bg/

White, D. (2016). What is Political Participation? - Definition, Forms \& Examples. Retrieved from https://study.com/academy/lesson/what-ispolitical-participation-definition-forms-examples.html

Young Bulgarians: more and more citizens of the world without interest in politics. (2019). Retrieved from https://www.clubz.bg/80504mladite_bylgari_vse_poveche_grajdani_na_sveta_bez_inter km_politikata 
